\title{
ASSOCIATIONS BETWEEN ALBUMIN LEVEL, LENGTH OF STAY, AND MORTALITY, IN ELDERLY PATIENTS WITH HEART FAILURE
}

\author{
Frans Wantania' ${ }^{1)}$, Ribka Wowor ${ }^{2)}$, Jeff Nangoy ${ }^{1)}$ \\ 1)Department of Medical Faculty, Sam Ratulangi University, Manado \\ 2)Department of Public Health, Sam Ratulangi University, Manado
}

\begin{abstract}
Background: Heart failure is a medical condition with high mortality. There are some known predictors of mortality among patients with heart failure. This study aimed to determine the associations between albumin level, length of stay, and mortality in elderly patients with heart failure.

Subjects and Method: This was an cohort study conducted at Prof Dr. RD Kandou Hospital, Manado, North Sulawesi. This study was carried out 4 months since April 2016. A sample of elderly patients aged $\geq 60$ years with heart failure were selected for this study. Patients with malignancy, cirrhosis hepatis, chronic kidney disease, and severe anemia, were excluded from this study. The dependent variables were length of stay (LOS) and mortality. The independent variable was albumin level. Associations between variables were measured by correlation coefficient.
\end{abstract}

Results: Mean level of albumin was $3.21 \mathrm{~g} / \mathrm{dL}$, mean of LOS was 7.95 days. LOS was negatively correlated with albumin level $(\mathrm{r}=-0.42 ; \mathrm{p}=0.004)$. Mortality was positively correlated with albumin level $(r=-0.22 ; \mathrm{p}=0.079)$.

Conclusion: LOS is negatively correlated with albumin level. Mortality is positively correlated with albumin level among elderly with heart failure.

Keywords: heart failure, albumin, length of stay, mortality

Correspondence: Frans Wantania. Department of Medical Faculty, Sam Ratulangi University, Manado. 